\title{
Geographic and Temporal Variation in Annual Survival of a Declining Neotropical Migrant Hummingbird (Selasphorus rufus) Under Varying Fire, Snowpack, and Climatic Conditions
}

\section{OPEN ACCESS}

Edited by:

Brett K. Sandercock,

Norwegian Institute for Nature

Research (NINA), Norway

Reviewed by:

Ethan Temeles,

Amherst College, United States

Ben Becker,

National Park Service, United States

*Correspondence:

Anna Drake

drake.ae@gmail.com

Specialty section: This article was submitted to

Population, Community, and Ecosystem Dynamics,

a section of the journal

Frontiers in Ecology and Evolution

Received: 29 November 2021

Accepted: 03 January 2022

Published: 31 January 2022

Citation:

Drake A, Bishop CA, Moran AJ and Wilson S (2022) Geographic and Temporal Variation in Annual

Survival of a Declining Neotropical Migrant Hummingbird (Selasphorus rufus) Under Varying Fire, Snowpack,

and Climatic Conditions.

Front. Ecol. Evol. 10:825026. doi: 10.3389/fevo.2022.825026

\author{
Anna Drake ${ }^{1 *}$, Christine A. Bishop ${ }^{2}$, Alison J. Moran ${ }^{3}$ and Scott Wilson ${ }^{1,2}$ \\ ${ }^{1}$ Department of Forest and Conservation Sciences, University of British Columbia, Vancouver, BC, Canada, ${ }^{2}$ Wildlife \\ Research Division, Science and Technology Branch, Environment and Climate Change Canada, Delta, BC, Canada, ${ }^{3}$ Rocky \\ Point Bird Observatory, Hummingbird Project, Victoria, BC, Canada
}

Rufous hummingbirds (Selasphorus rufus) have shown consistent declines in abundance since 1970, with an acceleration in this trend starting in the mid-2000s. Demographic data is needed to isolate possible drivers. We employ mark-recapture data to calculate sex-specific adult apparent annual survival, accounting for residency probability, within the coastal and interior regions of British Columbia, Canada between 1998 and 2017. For the coastal region, we also examine associations between apparent survival and a suite of migratory factors: the amount of recently and historically burned flyway habitat, fall moisture availability in the alpine (snowpack), and a broad-scale climate index (SOI), under the assumption that these factors are associated with food availability during a critical period of the annual cycle. We find no trend in adult apparent survival over the 20-year period, implicating changes in recruitment rather than adult survival as driving the declining trend in abundance. Interior birds of both sexes showed lower residency probability than coastal individuals suggesting interior sites captured more late northbound individuals or more early southbound individuals within the breeding period. Adult apparent annual survival was not correlated with any of the migratory variables we examined. Our findings suggest a need to focus on juvenile recruitment as a possible driver of the long-term declines in Rufous Hummingbirds. Future studies should consider both potential threats to productivity on the breeding grounds and to juvenile survival on the non-breeding grounds.

Keywords: Trochilidae, Selasphorus rufus, capture-recapture, apparent survival, neotropical migrant birds, demographic trends, conservation

\section{INTRODUCTION}

The broad-scale annual movements of migratory bird species make them both vulnerable and more difficult to conserve than residents (Lin et al., 2020). In the Americas, more than half of Nearctic-Neotropical migrants are in decline, reflecting ongoing habitat loss, the intensification of agricultural practices, and other anthropogenic harms (Rosenberg et al., 2019). To effectively 
conserve migrants, we need to understand and mitigate the key threats they face within their annual cycles; identifying potential drivers of demography is an important first step in this process (Rousseau et al., 2020).

As the smallest Nearctic-Neotropical migrants, the thirteen hummingbird species that breed within temperate North America represent a particularly difficult group to study (Partners in Flight, 2021). Eight of these species have sufficient Breeding Bird Survey data to model population trends (Partners in Flight, 2021); of these, three have significant declines between 1970 and 2020 (Selasphorus rufus, S. sasin, and S. platycercus) while a fourth (Archilocus colibris) has shown strong declines in the last decade. Rufous hummingbirds (Selasphorus rufus) are designated as near-threatened by the IUCN (BirdLife International, 2021) and are considered a priority species for conservation and/or stewardship in two Bird Conservation Regions (ECCC, 2019). Their abundance has declined by $65 \%$ since 1970 at an average rate of $-2.1 \%$ year (English et al., 2021a). Rufous hummingbirds occupy diverse habitats over their annual cycle and threats to this species could originate over a broad geographical area: their nonbreeding range encompasses the Mexican plateau, Sierra Madre, and western regions of Mexico (an area of conservation concern; Wilson et al., 2019) as well as the southeastern United States, while their breeding range extends across much of western North America, as far north as coastal southeastern Alaska (Healy and Calder, 2006; Moran et al., 2013; Fink et al., 2020).

Growing evidence suggests that threats during the nonbreeding period underlie declines of some long-distance passerine migrants (Morrison et al., 2013; Taylor and Stutchbury, 2016; Wilson et al., 2018). Although hummingbirds have a very different energetic and physiological profile than passerines, the migratory period may be a critical period for Rufous hummingbirds for three reasons outlined below.

First, it has been demonstrated that a large percentage of annual mortality for neotropical migrants occurs during migration (44-85\%; Sillett and Holmes, 2002; Paxton et al., 2017; Rockwell et al., 2017; Rushing, 2019). Movement periods are periods of vulnerability due to their metabolic costs, the need to traverse hostile and (for juveniles) unfamiliar landscapes, and increased competition for limited resources (Moore et al., 2005). Migrant hummingbirds may be especially constrained and vulnerable during migration due to their physiology. Though metabolically efficient (Powers et al., 2015; Shankar et al., 2020) and capable of large increases in mass (the upper $0.1 \%$ of Rufous hummingbirds in this study ranged from 4.8 to $6.4 \mathrm{~g}$, unpublished data), hummingbirds' small body size and high metabolism limit their ability to store energy relative to larger species (Brown et al., 1978; Suarez, 1992; Powers et al., 2015). This means that Rufous hummingbirds migrate at slower rates and spend relatively longer periods on the flyway than many other neotropical migrants (Woodrey and Chandler, 1997; Supp et al., 2015; Rousseau et al., 2020). For example, a Rufous hummingbird breeding in southern British Columbia likely spends $\sim 45-82$ days on the flyway per movement period during which time it might traverse $\sim 600$ $1,200 \mathrm{~km}$ in single flights of $14-28 \mathrm{~h}$ (Calder and Jones, 1989) and then pause at stop-over sites for several days to 3 weeks in order to rebuild muscle and replace fat stores (Carpenter et al., 1993a).
Secondly, the western North American landscapes through which Rufous hummingbirds migrate have experienced dramatic changes over the past century, including warmer, drier conditions (Knowles et al., 2006), increased wildfire intensity and coverage since 1980 (Littell et al., 2009; Marlon et al., 2012), the loss of most of its riparian habitat (Krueper, 1993), and increasing pesticide use in agriculture and forestry (NCASI, 2009; Bishop et al., 2018; Graves et al., 2019).

Finally, flowering plant phenology influences migration corridors and timing: Rufous hummingbirds are common in early blooming lowland riparian regions of the Pacific coast during the spring and late-blooming alpine meadows within the Rockies and the Sierra Nevada in the fall (Russell et al., 1994; Gillespie et al., 2020; Rousseau et al., 2020). Although other energetic sources are used by Rufous hummingbirds (Powers et al., 2010), they rely to a great extent on nectarivory. This may make them more sensitive to shifts in climate and weather than migrants feeding exclusively at higher trophic levels, through impacts on flower density, nectar production, and plant phenology (Russell et al., 1994; Supp et al., 2015).

Canada hosts $\sim 57 \%$ of the global breeding population of Rufous hummingbirds, almost entirely within the province of British Columbia (Partners in Flight, 2020). In order to help inform population management, we used 21 years (19972017) of long-term mark-recapture data from hummingbirds banded in southern BC as part of the Hummingbird Project (rpbo.org/hummingbirds). The data set represented 11,618 individuals marked at 14 banding stations on the coast and 11 stations in the interior of the province (Figure 1). We then applied a modeling approach that estimated temporal patterns in sex-specific apparent survival while accounting for the probability that individuals were breeding residents and the probability of among-year recaptures of marked individuals (Saracco et al., 2010; Wilson et al., 2018). Using this approach, our first objective examined whether low or declining adult survival is likely underlying long-term trends in abundance (English et al., 2021a). For coastal populations, where we had more records, our second objective then tested the hypothesis that changing migratory conditions drive variation in inter-annual survival. Specifically, we predicted that adult survival would co-vary with habitat availability (the percentage of the flyway recently burned by wildfires and the percentage of post-burn successional habitat), drought (snowpack depth in the Sierra Nevada and Rocky Mountains), and broad scale climate patterns (SOI), as detailed below and summarized in Table 1 .

Since 1980, there has been an increase in the number and severity of fires in western North America (Knowles et al., 2006; Littell et al., 2009). In the short term, wildfires remove stopover habitat and possibly present a direct threat to migrant birds by exposing them to smoke and/or forcing them to deviate from their migratory paths (Gillespie et al., 2020). In contrast, postfire habitats tend to have high wildflower abundance and can be heavily used by Rufous Hummingbirds during fall migration (observed 2-4 years post burn in the Sierra Nevada; Alexander et al., 2020). In Mexican pine-oak, Rufous hummingbirds respond positively to fire up to 10 years post-burn (ContrerasMartínez, 2015). Availability of such successional habitat in the 
western United States has likely varied dramatically over the past 200 years: fire frequency was anomalously high in the mid-1800s due to expanding European settlement then, beginning in 1905, active suppression resulted in anomalously low fire frequency (Marlon et al., 2012). Over the past 100 years, the smallest total area burned annually in the American west occurred between 1950 and 1980 (Littell et al., 2009). We predicted that Rufous hummingbird survival would be negatively correlated with previous-year burn area but positively correlated with the amount of 2-10-year-old post-fire habitat.

Rufous hummingbirds commonly use alpine meadows during fall migration. Here, plants are impacted by spring snowpack depth. Less snow results in earlier snowmelt which can advance phenology, expose plants to frost events which may harm flower development, and lead to earlier dry-down of soils resulting in plant desiccation and reduced nectar availability (Inouye and McGuire, 1991; Wipf et al., 2009; Waser and Price, 2016; Winkler et al., 2018). For example, in the Colorado Rockies, the hummingbird-visited Delphinium nelsonii blooms later and at greater density in years with greater snow depth (Inouye and McGuire, 1991). Another species used by hummingbirds in the Colorado Rockies, Ipomopsis aggegata, shows a positive association between snowmelt input and nectar availability (Waser and Price, 2016). Similarly, Russell et al. (1994) suggest that snowmelt runoff may provide water to hummingbird-visited alpine flowers in the Sierra Nevada during dry periods. We therefore predicted that greater spring snowdepths in the year prior to the survival year would produce more favorable conditions for Rufous hummingbirds during fall migration and would result in higher survival rates.

Wetter winters and springs in northern Mexico and the southern United States are produced by above-average sea surface temperature anomalies in the Pacific (El Niño/negative SOI conditions; Nott et al., 2002; NOAA, 2021). Such conditions have been associated with higher apparent annual survival of Swainson's thrush (Catharus ustulatus) as well as higher productivity among neotropical migrants breeding in the Pacific Northwest (Nott et al., 2002;

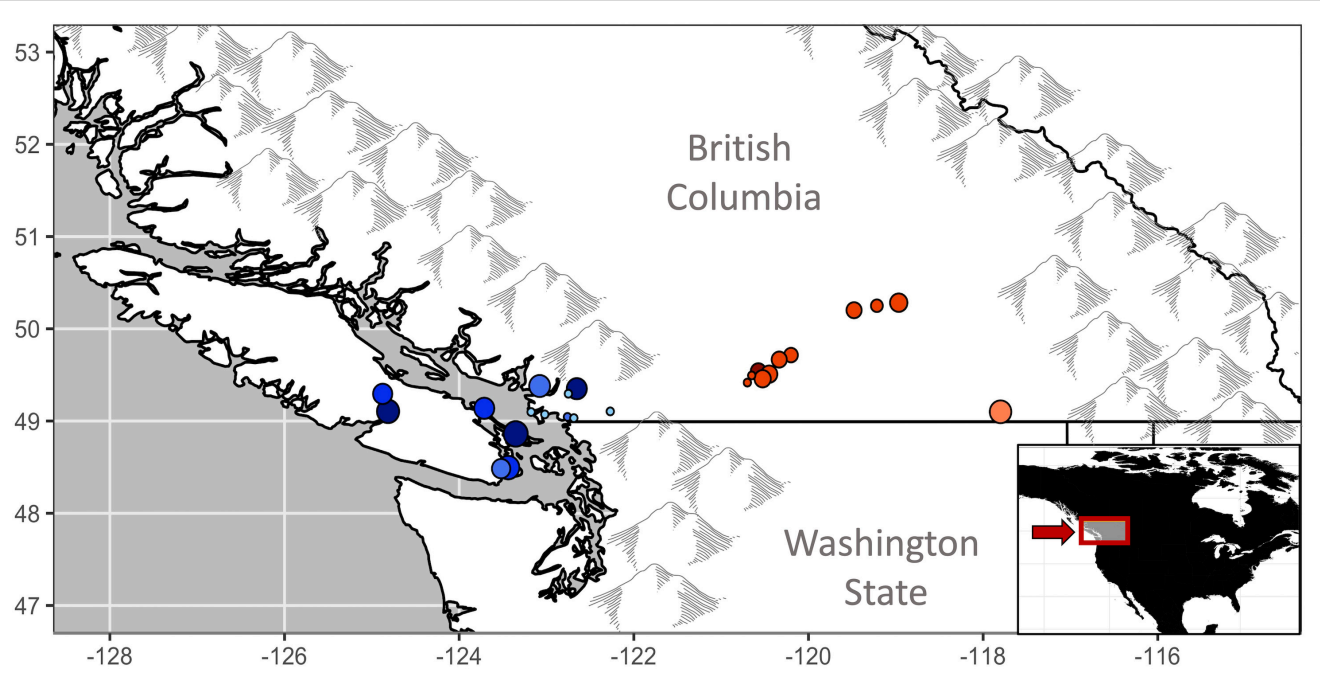

FIGURE 1 | Hummingbird monitoring project of BC mark-recapture locations in coastal (blue) and interior (red) regions of British Columbia, Canada. Clustered locations have been shifted $(<8 \mathrm{~km}$ ) for increased visibility. Point size reflects total years of banding effort, darker points reflect sites with higher Rufous hummingbird capture rates. Location details are additionally presented in Table 2.

TABLE 1 | Proposed drivers of variation in adult apparent annual survival for Rufous hummingbirds during the migratory period.

\begin{tabular}{|c|c|c|c|}
\hline Condition & Variable assessed & $\begin{array}{l}\text { Predicted } \\
\text { relationship }\end{array}$ & Reason \\
\hline Fire: recent-burn & $\begin{array}{l}\% \text { of flyway burned in the year prior to the } \\
\text { survival year }\end{array}$ & - & $\begin{array}{l}\text { Landscapes burned in the previous year cannot be used by migrating } \\
\text { hummingbirds. Fall fires and smoke present a migratory hazard during } \\
\text { southbound movement. }\end{array}$ \\
\hline $\begin{array}{l}\text { Fire: post-fire successional } \\
\text { habitat }\end{array}$ & $\begin{array}{l}\% \text { of flyway burned } 2-10 \text { years prior to the } \\
\text { survival year }\end{array}$ & + & $\begin{array}{l}\text { Post-burn successional habitat provide floral resources for migrating } \\
\text { hummingbirds. }\end{array}$ \\
\hline $\begin{array}{l}\text { Drought: alpine snowpack } \\
\text { depth }\end{array}$ & $\begin{array}{l}\text { Snow depth variation in Colorado Rockies and } \\
\text { the California Sierra Nevada }\end{array}$ & + & $\begin{array}{l}\text { Greater snow depth increases late-summer water availability for alpine } \\
\text { floral resources used by hummingbirds during fall migration. }\end{array}$ \\
\hline Broad climate variation & SOI index & - & $\begin{array}{l}\text { Negative SOI is associated with more rainfall in dry regions of western } \\
\text { North America which likely increases food availability. Positive SOI is } \\
\text { associated with more hostile migratory conditions. }\end{array}$ \\
\hline
\end{tabular}


TABLE 2 | Banding station locations, effort, and captures.

\begin{tabular}{|c|c|c|c|c|c|c|c|c|c|}
\hline \multirow[t]{2}{*}{ Location } & \multirow[b]{2}{*}{ Latitude } & \multirow[b]{2}{*}{ Longitude } & \multicolumn{3}{|c|}{ Effort } & \multicolumn{4}{|c|}{ Individuals banded } \\
\hline & & & Period active & Years active & Mean days/year (range) & Female & Male & Total & Birds/year \\
\hline \multicolumn{10}{|c|}{ A. Coastal sites } \\
\hline C1 & 49.032 & 122.687 & 2016-2017 & 2 & $3.0(3-3)$ & 9 & 1 & 10 & 5.0 \\
\hline $\mathrm{C} 2$ & 48.495 & 123.438 & 1997-2009 & 13 & $4.7(2-8)$ & 396 & 388 & 784 & 60.3 \\
\hline $\mathrm{C} 3$ & 48.484 & 123.444 & 2009-2017 & 9 & $4.8(1-7)$ & 338 & 106 & 444 & 49.3 \\
\hline $\mathrm{C} 4$ & 49.105 & 124.814 & 2004-2017 & 14 & $5.6(3-8)$ & 1,774 & 810 & 2,584 & 184.6 \\
\hline C5 & 49.138 & 123.713 & 2000-2010 & 11 & $4.4(1-6)$ & 822 & 186 & 1,008 & 91.6 \\
\hline $\mathrm{C} 6$ & 48.861 & 123.353 & 1997-2012 & 16 & $4.9(1-8)$ & 1,336 & 445 & 1,781 & 111.3 \\
\hline $\mathrm{C} 7$ & 49.380 & 123.079 & 2006-2017 & 12 & $2.2(1-3)$ & 265 & 10 & 275 & 22.9 \\
\hline $\mathrm{C} 8$ & 49.295 & 122.701 & 2015-2017 & 3 & $2.0(2-2)$ & 22 & 7 & 29 & 9.7 \\
\hline $\mathrm{C9}$ & 49.072 & 123.020 & 2015-2017 & 3 & $2.3(2-3)$ & 10 & 2 & 12 & 4.0 \\
\hline C10 & 49.294 & 124.876 & 2005-2014 & 10 & $5.0(4-6)$ & 547 & 310 & 857 & 85.7 \\
\hline C11 & 49.098 & 123.176 & 2015-2017 & 3 & $2.3(1-3)$ & 3 & 14 & 17 & 5.7 \\
\hline C12 & 49.045 & 122.701 & 2015-2017 & 3 & $3.0(3-3)$ & 43 & 50 & 93 & 31.0 \\
\hline C13 & 49.104 & 122.257 & 2015-2017 & 3 & $2.0(2-2)$ & 10 & 11 & 21 & 7.0 \\
\hline C14 & 49.351 & 122.650 & 2005-2015 & 11 & $4.7(2-7)$ & 1,409 & 519 & 1,928 & 175.3 \\
\hline \multicolumn{10}{|c|}{ B. Interior sites } \\
\hline 11 & 50.250 & 119.217 & 2005-2008 & 4 & $3.0(3-3)$ & 83 & 8 & 91 & 22.8 \\
\hline 12 & 49.494 & 120.509 & 2015-2017 & 3 & $4.0(2-5)$ & 49 & 17 & 66 & 22.0 \\
\hline 13 & 49.056 & 117.800 & 2005-2017 & 13 & $4.5(1-7)$ & 59 & 34 & 93 & 7.2 \\
\hline 14 & 49.537 & 120.514 & 2012-2017 & 6 & $5.0(1-9)$ & 121 & 268 & 389 & 64.8 \\
\hline 15 & 50.283 & 118.966 & 2010-2017 & 8 & $3.9(2-5)$ & 118 & 60 & 178 & 22.2 \\
\hline 16 & 49.508 & 120.515 & 2009-2015 & 7 & $3.0(1-6)$ & 45 & 60 & 105 & 15.0 \\
\hline 17 & 49.715 & 120.200 & 2013-2017 & 5 & $5.6(3-9)$ & 84 & 42 & 126 & 25.2 \\
\hline 18 & 50.201 & 119.478 & 2004-2009 & 6 & $4.7(1-7)$ & 118 & 18 & 136 & 22.7 \\
\hline 19 & 49.667 & 120.335 & 2012-2017 & 6 & $4.2(1-6)$ & 75 & 201 & 276 & 46.0 \\
\hline 110 & 49.417 & 120.583 & 2015-2017 & 3 & $5.0(5-5)$ & 8 & 24 & 32 & 10.7 \\
\hline 111 & 49.458 & 120.525 & 2011-2017 & 7 & $5.4(1-9)$ & 145 & 138 & 283 & 40.4 \\
\hline
\end{tabular}

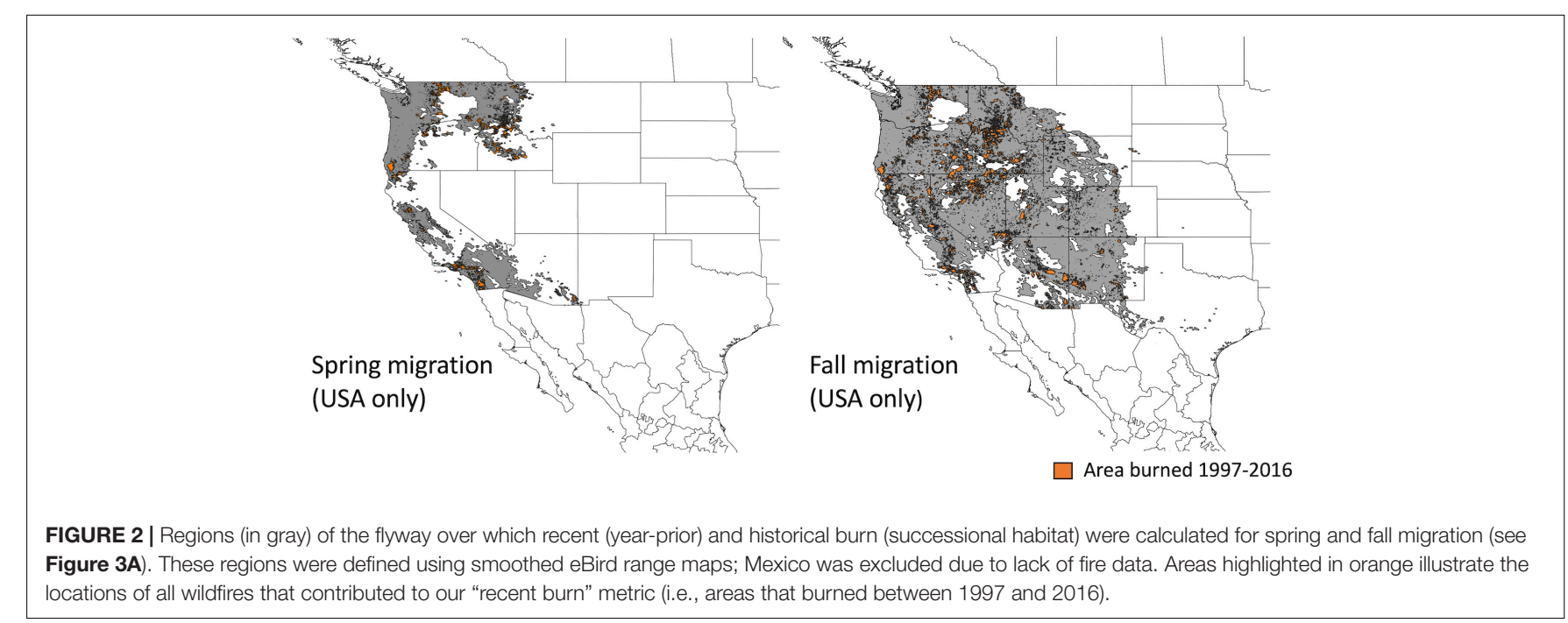

LaManna et al., 2012). Alpine meadows in the Sierra Nevada may also be more productive during El Niño events (Russell et al., 1994). In contrast, La Niña/positive SOI conditions produce stronger westerly winds blowing off of the Pacific during spring migration: conditions that are associated with lower apparent annual survival in larger western migrants (Drake et al., 2014; Huang et al., 2017). Thus, we predicted that negative SOI years would be more favorable for migrant hummingbirds and positive SOI years would be more hostile. 


\section{MATERIALS AND METHODS}

\section{Data Collection}

The Hummingbird Project (originally under the aegis of Cam Finlay) is a citizen science program run by Rocky Point Bird Observatory. The project has collected mark-recapture data on Rufous hummingbirds in British Columbia since 1997. Banding occurs weekly to bi-weekly (depending on site and year) beginning in early April (coastal sites) or early May (interior sites). Birds are captured using modified Hall traps (Russell et al., 2019) suspended over hummingbird feeders containing white sugar and water solution (e.g., Bishop et al., 2018). Individuals are aged and sexed based on Pyle (1997), their morphometric data is recorded, and they are then fitted with a Canadian Wildlife Service aluminum band or identified as recaptures.

We restricted banding records according to coastal and interior breeding periods (coastal males and females April 1June 20 and April 8-June 27, respectively; interior males and females May 1- June 30, May 8-July 14, respectively) for 19972017. Site effort for included records averaged 4.6 days/year/site (range: 1-8 days) on the coast and 4.4 days/year/site (1-9 days) in the interior. Within these years and date windows, 2,859 males and 6,984 females were banded on the coast and 870 males and 905 females were banded in the interior. Fewer male than female captures are likely partially driven by males departing from breeding territories earlier than females (A Moran, pers. obs., Rousseau et al., 2020) and therefore being less-available during the breeding season. Site-specific location data, captures, and effort are reported in Table 2.

\section{Migration Effect Model: Coastal Birds Only Migratory Range}

We used smoothed eBird range maps to define the regions used by Rufous hummingbirds during spring and fall migration (Fink et al., 2020). Boundaries are produced using modeled occurrence data aggregated at a $9 \mathrm{~km} 2$ grid-cell resolution (Figure 2). For our study population, we cropped the migratory region to the US border with Canada $\left(49^{\circ} \mathrm{N}\right)$, because our monitoring sites occurred in the southern portion of the province, close to the Canada-United States border [Figure 1, mean (range): $55 \mathrm{~km}(3-143 \mathrm{~km})]$. We additionally removed migratory regions that overlapped with the stationary nonbreeding period in Mexico.

\section{Environmental Variable Selection and Quantification Habitat-Fire Impacts}

We obtained United States fire perimeter data for 1988-2016 from the US National Interagency Fire Center Open Data portal (NIFC, 2021). Monitoring sites were in southern British Columbia (see above) and we therefore did not include Canadian fire perimeters (Figure 2). Fire perimeter data within Mexico did not cover all years and we also omitted this portion of the flyway for fire statistics (Figure 2). The removal of the Mexican portion of the flyways means that we are missing fire data for $21 \%$ of the surface area of the spring migratory region (primarily in Sonora and Baja Norte) and $6 \%$ of the surface area of the fall migratory region (primarily in Sonora and Chihuahua). We acknowledge that habitats in Sonora and Baja Norte are likely important for migrant hummingbirds in the spring due to their proximity to the ecological barrier of the southwestern deserts.

US fire perimeters were cropped to their overlap with Rufous hummingbird migratory regions (Figure 2) using QGIS (v. 3.10). Annual burn values were calculated as the percentage of the given flyway region that had burned the year prior to the survival year (i.e., 1997-2016 for survival years 1998-2017) (Figure 3A). Ideally, our burn area metric should include fires that occurred during spring of the survival year; however, fire initiation month was not available in the NIFC dataset and we therefore were unable to distinguish fires that occurred in the spring and fall. Most large fires in the western United States occur in fall. Detailed data from California show that the total area burned in this state between January and mid-May accounted for only $2.8 \%$ of the total area burned each year from 2013 to 2017 (range: 0.086.9\%; State of California, 2021). We therefore do not believe that omitting spring burns within the survival year distorts our metric. The percentage of the spring and fall migratory regions that burned annually were highly correlated (Pearson's $r=0.82$ ) and we therefore used only one metric (fall) in our model.

We quantified post-fire successional habitat as percentage of each flyway that had burned 2-10 years before the survival year. To obtain historic burn area, we merged all fire perimeter layers at 9-year intervals, beginning with 1988-1996 and ending with 2007-2015 (for survival years 1998-2017). We then removed any area that re-burned in the year prior to the survival year, as unavailable. Again, spring and fall migratory region values were highly correlated $(r=0.97)$ and we used the fall metric only in our model (Figure 3A).

\section{Climate-Snowpack}

We obtained historical statewide average snow-depth in April, calculated across multiple snow telemetry (SNOTEL) sites in California and Colorado, as an indicator of the condition of alpine meadows in the Sierra Nevada and the Rocky Mountains during fall migration. For California, these values are reported at the Department of Water Resources California Data Exchange Center (CDEC, 2021) as a proportion of the April 1st snowdepth average for 1951-2000. For Colorado, these values are reported at the USDA Natural Resources Conservation Service Colorado (USDA, 2021) as a proportion of the 1981-2010 median snow-depth (Figure 3B).

\section{Climate-Southern Oscillation Index}

We used the mean SOI index between June (year prior)-May of the survival year (NOAA, 2021) as a broader metric of annual conditions that encompass both wintering and migration periods (Figure 3C).

None of our environmental variables were so strongly correlated as to be confounded (i.e., all Pearson's $r<0.7$ ). California and Colorado snowpack depth did co-vary (Pearson's $r=0.52$ ). Total post-fire successional habitat increased over the monitoring period (by $0.2 \%$ of the flyway per year, $R^{2}=0.84$, $P<0.001$; Figure 3A). No other environmental variable showed a 

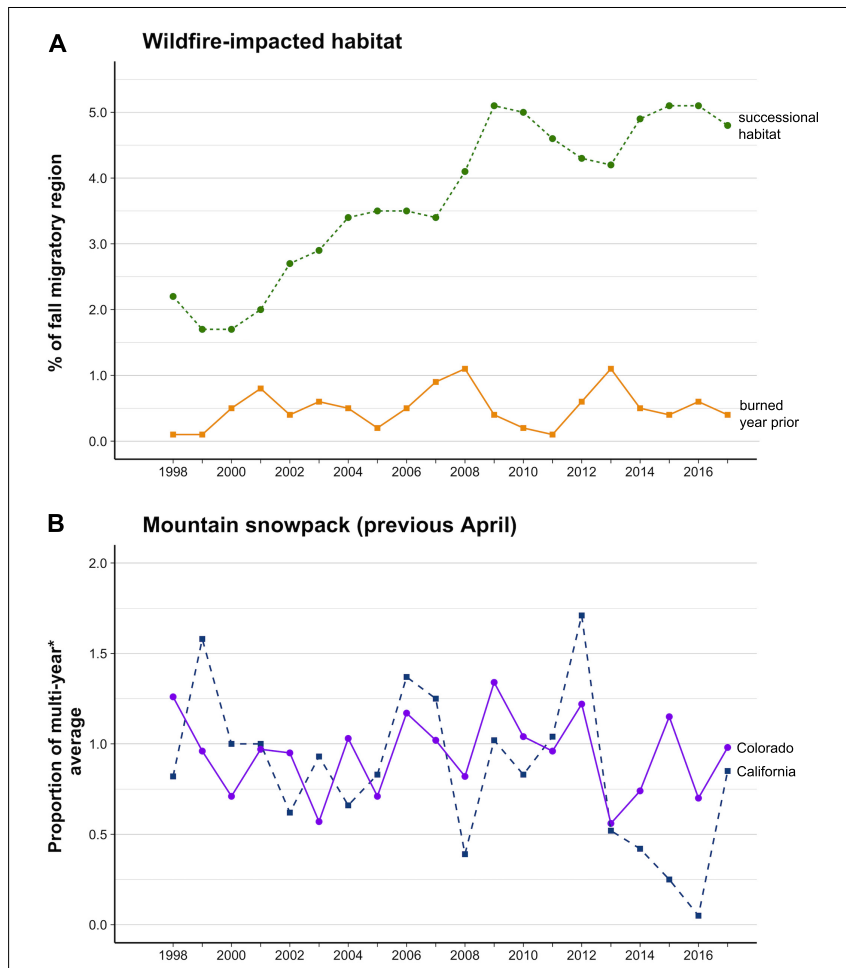

C

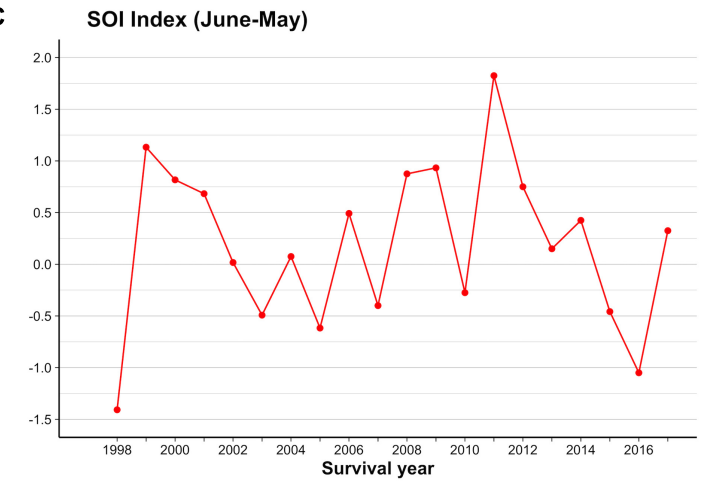

FIGURE 3 | Variation in migratory environmental variables over the mark-recapture period (1998-2017). (A) The percentage of the fall migratory region burned 2-10 years before the survival year ('successional habitat') and one year before to the survival year ('burned year prior'), (B) Relative April snowpack depth in the Colorado Rockies and California Sierra Nevada in the year before the survival year and, (C) SOI climate index.

temporal trend. Annual variation for all environmental variables is shown in Figure 3.

\section{General Survival Model: Coastal and Interior Birds}

Our survival model was a hierarchical formulation of the transient Cormack-Jolly Seber model (Hines et al., 2003; Saracco et al., 2010; Wilson et al., 2018) using individual encounter histories during annual sampling occasions. Hummingbird captures include transient individuals that are passing through the banding station and migrating to breeding sites elsewhere.
Our model allowed for a separate estimation of the probability that an individual was a resident in the local study area $(\pi)$, which provides both a more accurate estimate of apparent survival $(\phi)$ as well as a measure of the proportion of marked individuals estimated to be resident breeders within the study area. Our model also included probability of recapture and a probability of predetermining residency. Recapture probability $(p)$ is the probability of recapturing an individual marked in a previous year given that it is alive and in the study area. Predetermined residency $(\rho)$ is the probability of identifying an individual as a resident. The latter is informed using the proportion of individuals confirmed as breeding residents because they were captured on multiple occasions during sampling periods withinyear.

The probabilities for apparent survival and residency of individual $i$ at time $t$ was estimated with an annually varying intercept ( $\mu$ and $\alpha$, respectively), an influence of region $\left(\beta_{\phi, 1}\right.$, $\left.\beta_{\pi, 1}\right)$, sex $\left(\beta_{\phi, 2}, \beta_{\pi, 2}\right)$, and station level variance $\left(\omega_{s}\right)$. For apparent survival we also examined temporal trends by region and sex to examine whether apparent survival had declined over time for males and females in either region $\left(\beta_{\phi, 3_{k s}}\right)$. Probabilities were expressed on the logit scale as:

$\operatorname{logit}\left(\phi_{i, t}\right)=\mu_{\phi, \mathrm{t}}+\beta_{\phi, 1} *$ region $_{i}+\beta_{\phi, 2} * \operatorname{sex}_{i}+\beta_{\phi, 3_{k s}} * t+\omega_{\phi_{s}}$

$$
\operatorname{logit}\left(\pi_{i, t}\right)=\alpha_{\pi, t}+\beta_{\pi, 1} * \text { region }_{i}+\beta_{\pi, 2} * \operatorname{sex}_{i}+\omega_{\pi s}
$$

Our model produced survival estimates for the interior population prior to monitoring in that region (i.e., 19982004) based on coastal values in that period and the regional and station-level effects derived from the joint monitoring period (2005-2017). We do not report these un-monitored year estimates in Figure $\mathbf{4}$ as they are not informed by concurrent interior data. We do use these estimates to calculate the median sex-specific survival and residency in the interior between 1998 and 2017, allowing for a fair comparison between regions. We also present median sexspecific survival and residency for the joint monitoring period only (2005 and 2017).

The recapture probability was also estimated with an annually varying intercept, an effect of sex and station level variance but we did not include a region effect because methods were the same between the two regions and therefore, recapture probability was not expected to vary. Predetermined residency was only estimated with a constant intercept and an effect of sex since we did not expect this estimate to vary by region, year, or station:

$$
\begin{gathered}
\operatorname{logit}\left(p_{i, t}\right)=\gamma_{p, \mathrm{t}}+\beta_{p} * \operatorname{sex}_{i}+\omega_{\pi s} \\
\operatorname{logit}\left({ }_{i, t}\right)=v_{\rho}+\beta_{\rho} * \operatorname{sex}_{i}
\end{gathered}
$$

We fit our model using Markov Chain Monte Carlo methods in JAGS. For all beta values, we used an uninformative normal prior with a mean of 0 and precision of 0.01 but truncated the mean to a range of $(-8,8)$ to improve convergence. Banding station-level variation in residency, 


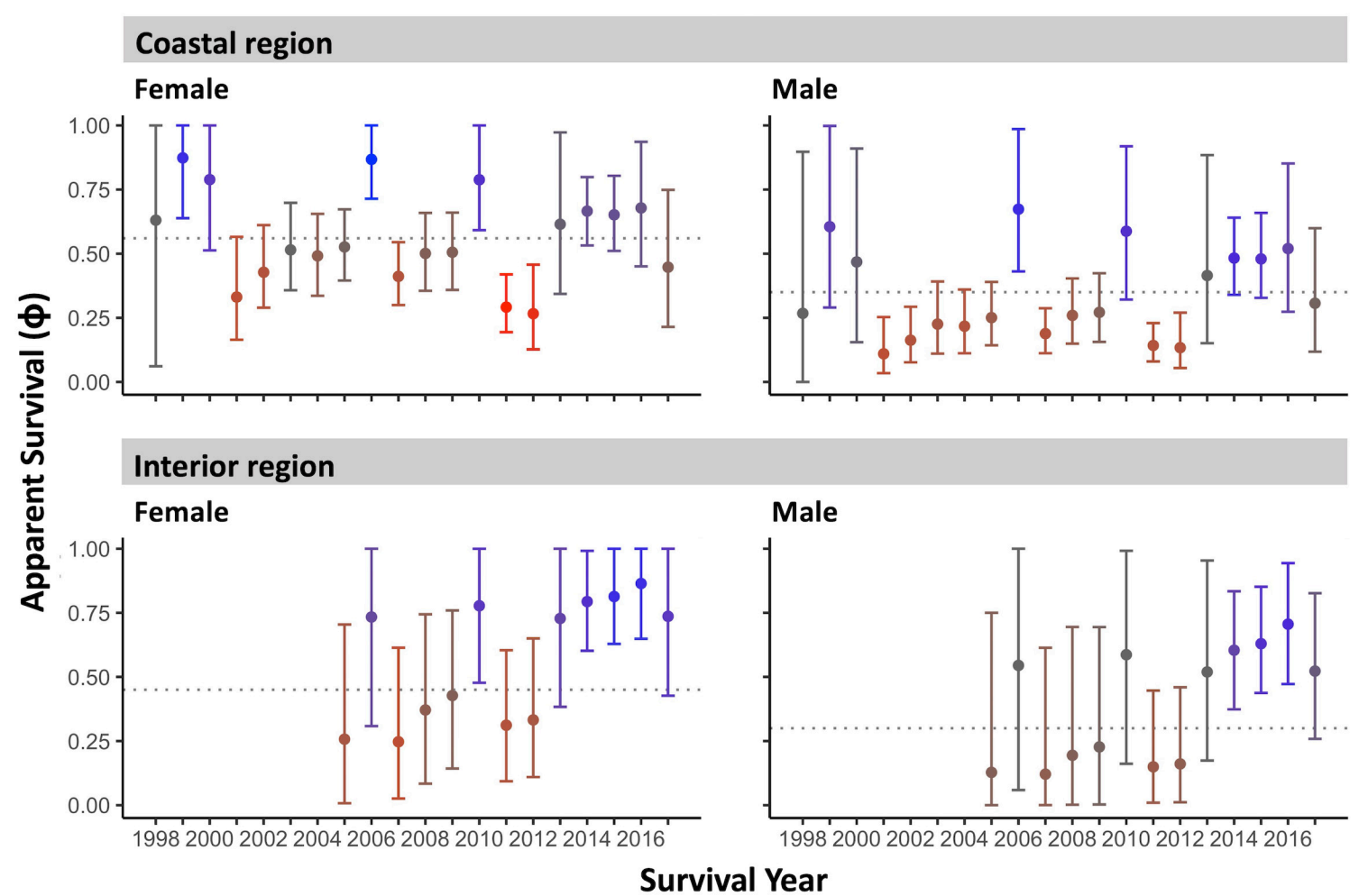

FIGURE 4 | Adult apparent annual survival (median \pm 95\% Cl) by sex and region over the 1998-2017 monitoring period. Dashed horizontal lines indicate the group inter-annual average survival. Color coding indicates anomalously high (blue) and anomalously low (red) survival years (see Methodology).

recapture, and apparent survival were incorporated as mean 0 random effects with a uniform distribution for the precision $(\mathrm{sd}=0,4)$.

JAGS was implemented through $\mathrm{R}$ using the package "runjags" (ver. 2.0.4-6; Denwood, 2016). For our general survival model, we ran two chains with an adaptation period of 1,000 iterations, a burn-in period of 14,000 iterations and an additional 5,000 iterations thinned by 5 , thus retaining 1,000 iterations from the posterior distribution for inference. We assessed model convergence through the parameter history plots and R-hat convergence diagnostics.

We quantified low- and high-survival years in two ways. First, we plotted annual survival estimates with their 95\% CI against the median inter-annual survival of the entire period for each sex and region grouping (Figure 4). Secondly, we quantified how anomalous each year was within the monitoring period for each group. This was done by summing the number of annual survival estimates in the time series that differed significantly from the given year's survival (i.e., where survival estimates did not overlap at the $84 \% \mathrm{CI}$; MacGregor-Fors and Payton, 2013). This score ranged from 0 to 13 years (color scale, Figure 4).

\section{Migration Model Parameterization}

Our migration model was fit identically to our general survival model above, dropping the trend parameter and adding our five migration variables as predictors. We standardized these migratory variables and included an interaction with sex. We anticipated environmental effects on survival would differ between the sexes due to migratory route and timing differences as well as intra-specific competition. For example, we predicted that females and not males would show a response to California snowpack values because females are more likely to migrate further west, including through the Sierra Nevada during fall, while males predominantly use the Rockies (Rousseau et al., 2020). Rufous hummingbirds are territorial throughout their annual cycle, including at migratory stopover sites. Adult males migrate earlier than other classes, reducing intraspecific competition enroute; however, among concurrent migrants, females, particularly juveniles, tend to defend larger, less flower-dense territories than juvenile and adult males at shared stopover sites (Kodric-Brown and Brown, 1978; Carpenter et al., 1993b). Thus, competitive exclusion could make female survival more responsive to variable conditions (but see Kodric-Brown and Brown, 1978; Carpenter et al., 1993c).

For our migration model we ran two chains for an adaptation period of 2,000 iterations and then discarded the following 60,000 iterations as burn-in. A further 75,000 iterations were thinned by 5 to give 15,000 samples from the posterior distribution for inference. As above, we assessed model convergence through the parameter history plots and R-hat convergence diagnostics. 


\section{RESULTS}

\section{General Survival and Trend Models: Coastal and Interior Birds}

Between 1997 and 2017, 9,843 individual Rufous Hummingbirds were banded across 14 stations in coastal BC. The average time period during which individual stations operated was 8 years and total effort was 116 station-years. Between 2004 and 2017, 1,775 individuals were banded across 11 stations in the $\mathrm{BC}$ interior. The average time period during which individual stations operated was 6 years and total effort was 68 stationyears. Site-specific location data, captures, and effort statistics are reported in Table 2; banding locations are also presented in Figure 1.

Female Rufous hummingbirds were significantly less likely than males to be recaptured [median probability $(95 \% \mathrm{CI})$ : females: $0.36(0.30-0.42)$ vs. males: $0.47(0.39-0.56)]$. This possibly reflects a lower propensity in females to visit feeders once floral resources and insects become more available in the spring. On the coast, females had significantly higher average inter-annual apparent survival than males [median (95\% CI): females: 0.56 (0.51-0.63), males: 0.35 (0.28-0.43)] and, overall, these females had the highest median apparent survivorship in the study. Coastal females showed higher than average survival in 1999, 2006, and 2010 and lower than average survival in 2007, and 2011-2012 (95\% CI did not cross the inter-annual median; Figure 4). Coastal males showed higher than average survival in 2006 and lower than average survival in 2001-2002, 2007, and 2011-2012 (Figure 4). Both coastal males and females had high residency probability [median (95\% CI): coastal males: 0.54 (0.38-0.71), coastal females: 0.62 (0.49-0.76); Figure 5]. Coastal female residency probability was higher than both sexes in the interior and coastal males had higher residency probability than interior females [interior males: 0.35 (0.19-0.52), interior females: 0.23 (0.11-0.36); Figure 5].

In general, confidence intervals were greater for interior birds due to smaller sample sizes, reducing our ability to make firm inferences about this population. Average interannual survival values for interior birds did not differ significantly from coastal individuals [females: 0.45 (0.23-0.73), males: 0.30 (0.13-0.72)]. Like coastal birds, interior data suggests higher female than male survival, however, the confidence intervals for both estimates for each sex are wide and show a high degree of overlap. Despite this lack of resolution, interior males and females showed higher than average survival in 2014-2016 and in 2010 for females (95\% CI did not cross the inter-annual mean) (Figure 4). We note that interior females had the lowest residency probability in the study (see above) although they were not statistically distinguishable from interior males (Figure 5).

The above relationships between inter-annual survival and residency estimates were consistent over the shorter, joint monitoring period (2005-2017) although their absolute values shifted. As above, regional survival could not be distinguished. Survival was higher for coastal females than coastal males [median (95\% CI): females $=0.55(0.50-0.61)$; males $=0.36(0.30-$ $0.43)$ ] while interior female survival had a higher median survival

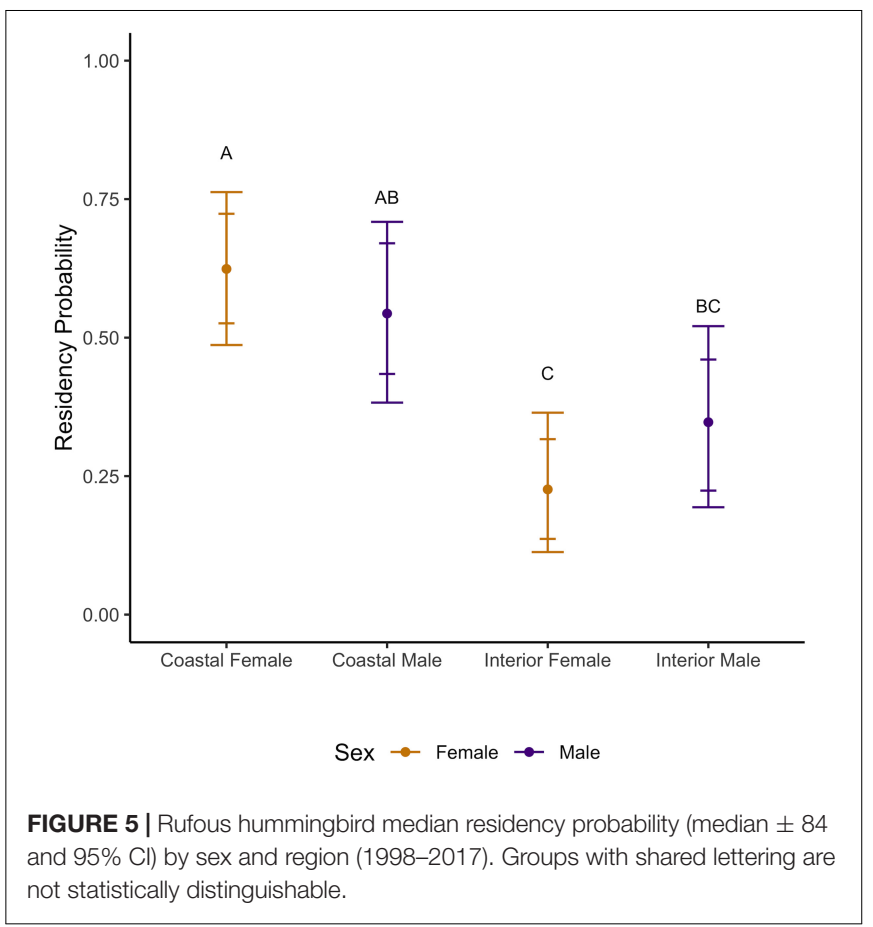

estimate than that of interior males but could not be distinguished statistically [females $=0.54(0.35-0.74)$, males $=0.39(0.19-0.70)]$. Coastal female residency probability was higher than that of both sexes in the interior and coastal males had higher residency probability than interior females [median (95\% CI): coastal males $=0.57(0.36-0.74)$, coastal females $=0.65(0.47-0.78)$, interior males $=0.32(0.18-0.50)$, interior females $=0.20(0.10-$ 0.33)].

Apparent annual survival estimates did not indicate a temporal trend in adult survival over the full 1998-2017 monitoring period for any sex or region [beta estimate (95\% CI): coastal males: $0.03(-0.10-0.17)$, coastal females: -0.02 ($0.15-0.12)$, interior males: $0.17(-0.17-0.55)$, interior females: $0.18(-0.12-0.55)]$.

\section{Migration Effect Model: Coastal Birds}

Post-burn, successional habitat on the flyway increased from $\sim 2$ to $\sim 5 \%$ of the fall migratory corridor over our 20year monitoring period (Figure 3A). Annual burns averaged $0.5 \%$ of the total fall migratory corridor, with 2006-2007 and 2012 experiencing above-average burn areas within the period (0.9-1.1\%; Figure 3A, with 1 year advancement for survival year). Annual snowpack in the Sierra Nevada was more variable than in the Colorado Rockies (Figure 3B, with 1-year advancement for survival year). The Sierra mountains had high snow accumulation in 1998 and 2011 and low accumulations between 2012 and 2015; California experienced the lowest snow accumulations in historical record in 2015 (5\% of the April 1 average for 1951-2000). The Colorado Rockies had high snow accumulation in 1997 and 2011 and the lowest accumulation in the monitoring period in 2012 (56\% of the median snow-depth 
for 1981-2010). SOI indices were most favorable in 1998 and least favorable in 2011 (Figure 3C).

Of the migratory variables tested, beta estimates for SOI had the largest absolute mean value and were in the direction predicted, however, all of our migratory variables had beta estimates that encompassed 0 within their $95 \% \mathrm{CI}$, indicating that none were key drivers of our observed survival probabilities (Figure 6).

\section{DISCUSSION}

Rufous hummingbird survival rates were variable over the 19982017 monitoring period but showed no evidence of a constant decline. This absence of a trend in adult survival is inconsistent with an apparent steepening decline in breeding abundance for this species beginning in the early 2000s (English et al., 2021a). Similar adult apparent survival rates to those we report here (see below) were observed in Ruby-throated hummingbirds during a period of population increase from 1984 to 2001 (Hilton and Miller, 2003; English et al., 2021a). These discrepancies suggest that demographic processes other than adult survival are driving declines in Rufous hummingbird abundance. Poor juvenile recruitment is considered a likely contributor to declining populations in other Neotropical migrants (Wilson et al., 2018; Zhao et al., 2022). Thus, identifying conditions associated with poor reproductive success and/or hatch year survival may be informative. Female productivity and nestling development may be negatively impacted by stressors associated with anthropogenic changes on the breeding grounds. Similarly, age-structured fall migratory routes, where hatch year birds

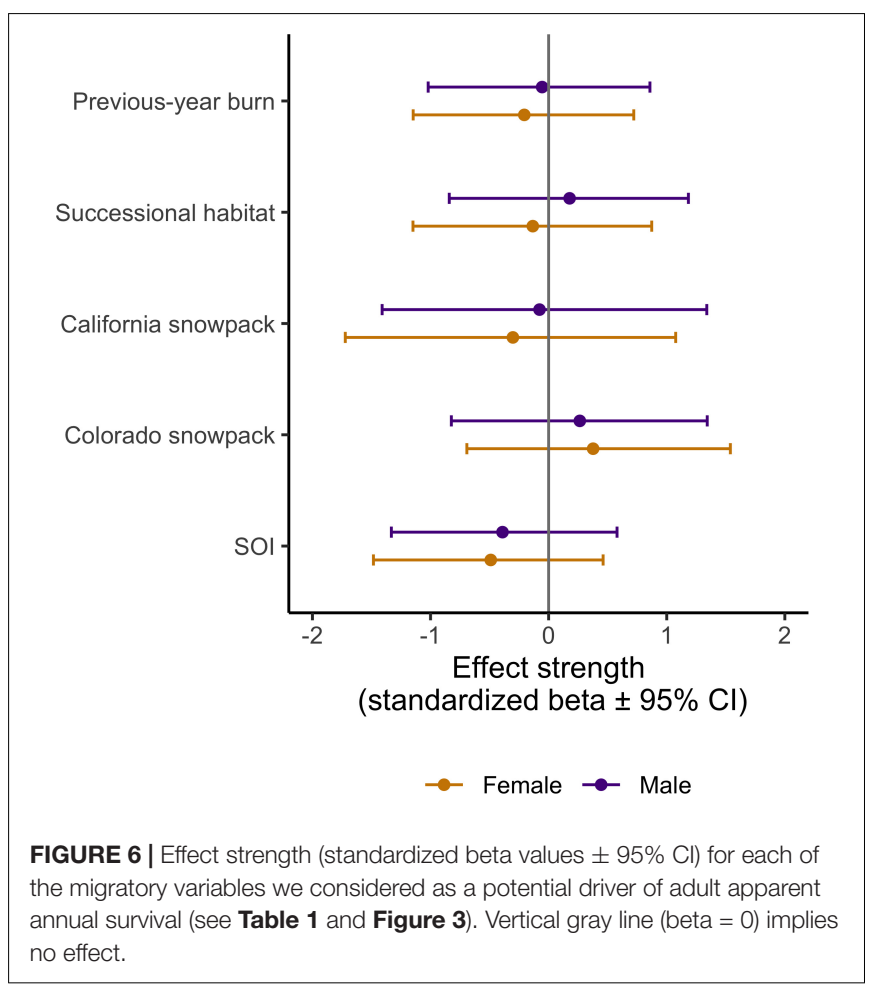

are more likely to migrate through lower-elevation landscapes, may make this class more vulnerable to anthropogenic stressors (Rousseau et al., 2020). The impact of exposure to pesticides with known avian reproductive, metabolic, and developmental effects within agricultural and forestry lands certainly warrants further study (Winnick and Dzialowski, 2013; Hoshi et al., 2014; LopezAntia et al., 2015; Bishop et al., 2018; English et al., 2021b) as does the possible loss of breeding habitat associated with herbicide use during forestry operations (Betts et al., 2013) and the impact of non-breeding habitat loss/degradation on juvenile survival (e.g., Wilson et al., 2018).

Our models provide the first measures of adult apparent annual survival for Rufous hummingbirds and only the third estimate for migratory hummingbird species as a group. Survival rates within the Trochilidae family are poorly documented (Wilson et al., 2011) but our apparent survival rates (0.30-0.56) correspond with the wide ranges reported in the literature for eight tropical and sub-tropical hummingbird species (0.32-0.70) (Stiles, 1992; Parker et al., 2006; Ruiz-Gutiérrez et al., 2012; Blake and Loiselle, 2013; Rodrigues et al., 2013; Williamson and Witt, 2021) and for the long-distance migrant Ruby-throated hummingbird (Archilochus colubris; 0.29-0.45) (Mulvihill et al., 1992; Hilton and Miller, 2003).

Coastal females showed higher average apparent survival than males; interior females may also have higher apparent survival compared to males in the same area, though larger sample sizes are needed for greater certainty around these estimates. Higher female apparent survival is consistent with sexspecific survival rates in Ruby-throated hummingbirds (males: $0.30 \pm 0.05$ SE; females: $0.43 \pm 0.04$; Hilton and Miller, 2003; see also Mulvihill et al., 1992) and in the resident Hyacinth Visorbearer (Augastes scutatus) in southeastern Brazil (males: $0.32 \pm 0.12$; females: $0.42 \pm 0.16$; Rodrigues et al., 2013). These estimates could reflect higher mortality and/or lower site fidelity in male hummingbirds. Males might experience higher mortality as a product of more precarious energetics, given their small body size, and territorial aggression during the breeding period (Calder et al., 1990; Mulvihill et al., 1992). For example, withinseason recaptures of Ruby-throated hummingbirds suggest high breeding season mortality among males (Mulvihill et al., 1992). Differential survival could produce female-biased sex ratios in Rufous hummingbirds, as has been observed in Ruby-throated hummingbirds (Weidensaul et al., 2020) and would be consistent with the polygynous breeding system exhibited by Trochilidae (Bleiweiss, 1992; Slagsvold and Lifjeld, 1994). Alternatively, male Rufous hummingbirds may seek breeding opportunities in multiple locations (Bailey et al., 2013) and this, combined with the high variance in reproductive success among males in polygynous systems (Wade, 1979), could result in low site-fidelity among unsuccessful males.

Within the breeding period, interior Rufous hummingbirds were less likely to be residents than coastal females. Interior female residency was also below that of coastal males. This difference could reflect late northbound (pre-breeding) or early southbound (post-breeding) migratory movement of individuals through interior banding sites. The trend toward lower female than male residency estimates in the interior (Figure 5) 
would be more consistent with stations capturing northbound movement, as females migrate later than males in both seasons (Rousseau et al., 2020).

Despite the many stressors hummingbirds encounter during migration (Gillespie et al., 2020), and the fact that coastal Rufous hummingbirds showed high inter-annual variation in survival, we did not find evidence that any of the suite of non-breeding factors we assessed had an impact on mortality. For example, there was little correspondence between snowpack depth and survival despite associations between food availability and snowmelt in the alpine. Any impact of snow-depth should have been particularly visible among females in 2016, given the historic "snow drought" in the Sierra Nevada and Cascade mountains in 2015. Snow-depth values for the Sierra Nevada that year were below any in the observational record (NIDIS, 2015). Despite this, female survival did not dip in 2016 and that year's rate fell within the inter-annual average. Indeed, the entire state of California experienced "abnormally dry" to "exceptional drought" conditions in the years 2014-2016 (NDMC, 2020), an event that also does not register in our time series.

Similarly, variation in fire dynamics on the flyway did not correspond with adult survival. This may be because the total percentage of historically burned habitat within the flyway is small ( $\leq 5 \%$ within our monitoring period) which may preclude Rufous hummingbirds from being strongly dependent on it during migration. It is also possible that our fire metrics fail to accurately reflect successional habitat availability. This could happen if our defined migratory corridors are too broad (due to lack of information), or because some post-fire successional habitat is not, in fact, suitable for migrants (e.g., in areas that experienced high intensity burns; Gillespie et al., 2020). We did not include timber harvest area in our estimate of successional habitat, though forest sites cleared by logging can be used by Rufous hummingbirds depending on the type of herbicides applied (Morrison and Meslow, 1984; Betts et al., 2013). Total timber volume harvested annually in the western US declined from $\sim 22,000$ million board-feet to $\sim 13,000$ between 1988 and 2015 (Daniels and Wendel, 2020). A reduction in postlogging successional habitat could therefore be partially offsetting increased post-burn area.

Smoke produced by wildfires can impact air quality and photosynthesis (McKendry et al., 2019) over large regions and it is notable that previous-year burns did not correspond with adult survival. In British Columbia, smoke from interior wildfires during the 2015 breeding period was associated with nest abandonment at some of our monitoring sites (Moran, pers. obs., 2015); fire may have a greater impact on productivity and hatch year survival than adult survival.

Although Rufous hummingbirds did not appear to respond strongly to SOI and its associated climate effects, it is still possible that extreme regional conditions and/or stochastic weather events (such as storms or cold-snaps) produce the variability in survival we observe. For example, the notable dip in survival in 2011 (Figure 3) corresponds with an anomalously cold, low NDVI winter in high elevation habitats within Mexico (Graham et al., 2016) as well as an extreme weather event within the Sonoran desert during February of that year where temperatures hit lows of -3 to $-8^{\circ} \mathrm{C}$ over a 4 -day period (Saguaro, Arizona (Meteorological Station ID:USR0000ASAG); Kreutz, 2012). As such events could occur in different locations or at different points in the annual cycle from year-to-year, these types of drivers would be difficult to quantify with the broad-scale approach employed here.

\section{CONCLUSION}

Overall, our study provides important information on demographic parameters for Rufous-hummingbirds but we did not identify any single, broad-ranging factor that might explain on-going abundance declines in this species. Although migratory conditions are plausible drivers of mortality in Rufous hummingbirds, given the metabolic demands of movement and the length of time on the flyway, variation in our candidate variables did not correspond with observed annual variation in adult survival. An examination of wintering conditions and/or extreme events on migration may yield stronger associations. Perhaps more importantly, our data indicate that adult survival in British Columbia did not decline between 1998 and 2017 despite population declines within the same period (English et al., 2021a). This would suggest that other, unmeasured, vital rates are the cause of declining abundance in Rufous Hummingbirds and that, possibly, these rates shifted for the worse in the early 2000s. We suggest juvenile recruitment, rather than low adult survival, may be a problem for this species. Future studies should examine threats to productivity on the breeding grounds and to juvenile survival within migratory and overwintering areas.

\section{DATA AVAILABILITY STATEMENT}

The raw data supporting the conclusions of this article will be made available by the authors, without undue reservation.

\section{ETHICS STATEMENT}

The animal study was reviewed and approved by the Western and Northern Animal Care Committee of Environment and Climate Change Canada.

\section{AUTHOR CONTRIBUTIONS}

$\mathrm{AD}$ : investigation (equal), formal analysis (equal), visualization (lead), writing-original draft (lead), and writing-review, and editing (equal). CB: conceptualization (equal), investigation (equal), and writing-review and editing (equal). SW: investigation (equal), methodology (lead), formal analysis (equal), and writingreview and editing (equal). AM: conceptualization (equal), investigation (equal), data curation (lead), and writing-review and editing (equal). All authors contributed to the article and approved the submitted version. 


\section{FUNDING}

Post-doctoral funding provided to $\mathrm{AD}$ by Environment and Climate Change Canada.

\section{ACKNOWLEDGMENTS}

We thank project initiators Cam and Joy Finlay, our generous site hosts, and the dedication of volunteer monitoring teams under

\section{REFERENCES}

Alexander, J. D., Williams, E. J., Gillespie, C. R., Contreras-Martínez, S., and Finch, D. M. (2020). Effects of Restoration and Fire on Habitats and Populations of Western Hummingbirds: a Literature Review. General Technical Reports RMRSGTR-408. Fort Collins, CO: USDA, Forest Service, Rocky Mountain Research Station.

Bailey, I., Segelbacher, G., Healy, S., Hurly, T., and Pemberton, J. (2013). Microsatellite variation in Rufous Hummingbirds (Selasphorus rufus) and evidence for a weakly structured population. J. Ornithol. 154. doi: 10.1007/ s10336-013-0971-2

Betts, M. G., Verschuyl, J., Giovanini, J., Stokely, T., and Kroll, A. J. (2013). Initial experimental effects of intensive forest management on avian abundance. Forest Ecol. Manag. 310, 1036-1044. doi: 10.1016/j.foreco.2013.06.022

BirdLife International (2021). Species factsheet: Selasphorus rufus. Cambridge: BirdLife International.

Bishop, C. A., Moran, A. J., Toshack, M. C., Elle, E., Maisonneuve, F., and Elliott, J. E. (2018). Hummingbirds and bumble bees exposed to neonicotinoid and organophosphate insecticides in the Fraser Valley, British Columbia, Canada. Environ. Toxicol Chem. 37, 2143-2152. doi: 10.1002/etc. 4174

Blake, J. G., and Loiselle, B. A. (2013). Apparent survival rates of forest birds in eastern Ecuador revisited: improvement in precision but no change in estimates. PLoS One 8:e81028. doi: 10.1371/journal.pone.0081028

Bleiweiss, R. (1992). Widespread polychromatism in female Sunangel hummingbirds (Heliangelus: Trochilidae). Biol. J. Linn. Soc. 45, 291-314. doi: 10.1111/j.1095-8312.1992.tb00646.x

Brown, J. H., Calder, W. A. III, and Kodric-Brown, A. (1978). Correlates and consequences of body size in nectar-feeding birds. Am. Zool. 18, 687-738. doi: $10.1093 / \mathrm{icb} / 18.4 .687$

Calder, W. A. III, and Jones, E. G. (1989). Implications of recapture data for migration of the rufous hummingbird (Selasphorus rufus) in the Rocky mountains. Auk 106, 488-489.

Calder, W. A., Calder, L. L., and Fraizer, T. D. (1990). The hummingbird's restraint: A natural model for weight control. Experientia 46, 999-1002. doi: 10.1007/ BF01940653

Carpenter, F. L., Hixon, M. A., Beuchat, C. A., Russell, R. W., and Paton, D. C. (1993a). Biphasic mass gain in migrant hummingbirds: body composition changes. Torpor Ecol. Signif. Ecol. 74, 1173-1182. doi: 10.2307/194 0487

Carpenter, F. L., Hixon, M. A., Russell, R. W., Paton, D. C., and Temeles, E. J. (1993b). Interference asymmetries among age-sex classes of Rufous hummingbirds during migratory stopovers. Behav. Ecol. Sociobiol. 33, 297-304. doi: 10.1007/BF00172927

Carpenter, F. L., Hixon, M. A., Temeles, E. J., Russell, R. W., and Paton, D. C. (1993c). Exploitative compensation by subordinate age-sex classes of migrant Rufous hummingbirds. Behav. Ecol. Sociobiol. 33, 305-312. doi: 10.1007/ BF00172928

CDEC (2021). Department of Water Resources California Data Exchange Center. Available online at: http://cdec.water.ca.gov/reportapp/(accessed January 4, 2022)

Contreras-Martínez, S. (2015). Dinámica espacio-temporal de colibríes (Trochilidae), en bosques de pino-encino post-incendio en la Reserva de la Biosfera Sierra de Manantlán, Jalisco, México. Doctoral Thesis, Ciencias the direction of their team leaders: Stan Acton, Alain BoisclairJoly, Sue Elwell, Mike Hoebel, Christina Lam, Gail Loughridge, Ben McKinnon, Devin Manky, Sharon Podesta, Keith Poulton, Shirley Prince, Linda Szymkowiak, Terry Tellier, Roy Teo, Debbie Wheeler, and Azim Shariff. We also thank A Rocha Canada, Capital Regional District Parks, George C. Reifel Migratory Bird Sanctuary, Goldstream Hatchery, Grouse Mountain Resort, Metro Vancouver Parks, staff at Minnekhada Lodge, Orphaned Wildlife Rehabilitation Society (OWL), and the Vancouver Avian Research Centre (VARC).

en Biosistemática, Ecología y Manejo de Recursos Naturales y Agrícolas., Departamento de Ecología y Recursos Naturales. Autlán: Universidad de Guadalajara-CUCSUR.

Daniels, J. M., and Wendel, K. (2020). Production, prices, employment, and trade in Northwest forest industries. Washington, DC: USDA. 19582019.

Denwood, M. J. (2016). runjags: an r package providing interface utilities, model templates, parallel computing methods and additional distributions for mcmc models in JAGS. J. Stat. Softw. 71, 1-25. doi: 10.18637/jss.v071.i09

Drake, A., Rock, C. A., Quinlan, S. P., Martin, M., and Green, D. J. (2014). Wind speed during migration influences the survival, timing of breeding, and productivity of a neotropical migrant, Setophaga petechia. PLoS One 9:e97152. doi: 10.1371/journal.pone.0097152

ECCC (2019). The Status of Birds in Canada Website: Rufous Hummingbird species account. Gatineau: Environment and Climate Change Canada.

English, S. G., Bishop, C. A., Wilson, S., and Smith, A. C. (2021a). Current contrasting population trends among North American hummingbirds. Sci. Rep. 11, 1-9. doi: 10.1038/s41598-021-97889-x

English, S. G., Sandoval-Herrera, N. I., Bishop, C. A., Cartwright, M., Maisonneuve, F., Elliott, J. E., et al. (2021b). Neonicotinoid pesticides exert metabolic effects on avian pollinators. Sci. Rep. 11:2914. doi: 10.1038/s41598-02182470-3

Fink, D., Auer, T., Johnston, A., Strimas-Mackey, M., Robinson, O., Ligocki, S., et al. (2020). eBird Status and Trends, Data Version: 2019 Cornell Lab of Ornithology, Ithaca. New York. doi: 10.2173/ebirdst.2019

Gillespie, C. R., Contreras-Martínez, S., Bishop, C. A., and Alexander, J. D. (2020). Rufous Hummingbird: State of the science and conservation. Boulder, CO: Western Hummingbird Partnership.

Graham, C. H., Supp, S. R., Powers, D. R., Beck, P., Lim, M. C. W., Shankar, A., et al. (2016). Winter conditions influence biological responses of migrating hummingbirds. Ecosphere 7:e01470. doi: 10.1002/ecs2.1470

Graves, E. E., Jelks, K. A., Foley, J. E., Filigenzi, M. S., Poppenga, R. H., Ernest, H. B., et al. (2019). Analysis of insecticide exposure in California hummingbirds using liquid chromatography-mass spectrometry. Environ. Sci. Pollut. Res. 26, 15458-15466. doi: 10.1007/s11356-019-04903-x

Healy, S., and Calder, W. A. (2006). "Rufous Hummingbird (Selasphorus rufus)," in Birds of the World, ed. A. F. Poole New York, NY: Cornell Lab of Ornithology. doi: 10.2173/bna.rufhum.02

Hilton, B., and Miller, M. W. (2003). Annual survival and recruitment in a rubythroated hummingbird population, excluding the effect of transient individuals. Condor 105, 54-62. doi: 10.1093/condor/105.1.54

Hines, J. E., Kendall, W. L., and Nichols, J. D. (2003). On the use of the robust design with transient capture-recapture models. Auk 120, 1151-1158. doi: 10 2307/4090285

Hoshi, N., Hirano, T., Omotehara, T., Tokumoto, J., Umemura, Y., Mantani, Y., et al. (2014). Insight into the mechanism of reproductive dysfunction caused by neonicotinoid pesticides. Biol. Pharma. Bull. 37, 1439-1443. doi: 10.1248/bpb. b14-00359

Huang, A. C., Bishop, C. A., McKibbin, R., Drake, A., and Green, D. J. (2017). Wind conditions on migration influence the annual survival of a neotropical migrant, the western Yellow-breasted chat (Icteria virens auricollis). BMC Ecol. 17:29. doi: 10.1186/s12898-017-0139-7

Inouye, D. W., and McGuire, A. D. (1991). Effects of snowpack on timing and abundance of flowering in Delphinium nelsonii (Ranunculaceae): implications 
for climate change. Am. J. Bot. 78, 997-1001. doi: 10.1002/j.1537-2197.1991. tb14504.x

Knowles, N., Dettinger, M. D., and Cayan, D. R. (2006). Trends in snowfall versus rainfall in the western United States. J. Clim. 19, 4545-4559. doi: 10.1175/ JCLI3850.1

Kodric-Brown, A., and Brown, J. H. (1978). Influence of economics, interspecific competition, and sexual dimorphism on territoriality of migrant Rufous hummingbirds. Ecology 59, 285-296. doi: 10.2307/1936374

Kreutz, D. (2012). Older saguaros are still paying a price after great freeze of 2011. Arizona Daily Star.

Krueper, D. J. (1993). "Effects of land use practices on western riparian ecosystems". in Finch, Deborah M.; Stangel, Peter W. (eds.). Status and management of neotropical migratory birds Estes Park: U.S. Dept. of Agriculture.

LaManna, J. A., George, T. L., Saracco, J. F., Nott, M. P., and DeSante, D. F. (2012). El Niño-Southern Oscillation influences annual survival of a migratory songbird at a regional scale - La Oscilación del Sur-El Niño Afecta la Supervivencia Anual de un Ave Canora Migratoria a Escala Regional. Auk 129, 734-743. doi: 10.1525/auk.2012.12017

Lin, H.-Y., Schuster, R., Wilson, S., Cooke, S. J., Rodewald, A. D., and Bennett, J. R. (2020). Integrating season-specific needs of migratory and resident birds in conservation planning. Biol. Conserv. 252:108826. doi: 10.1016/j.biocon.2020. 108826

Littell, J. S., McKenzie, D., Peterson, D. L., and Westerling, A. L. (2009). Climate and wildfire area burned in western U.S. ecoprovinces. 1916-2003. Ecol. Appl. 19:1003-1021 doi: 10.1890/07-1183.1

Lopez-Antia, A., Ortiz-Santaliestra, M. E., Mougeot, F., and Mateo, R. (2015). Imidacloprid-treated seed ingestion has lethal effect on adult partridges and reduces both breeding investment and offspring immunity. Environ. Res. 136, 97-107. doi: 10.1016/j.envres.2014.10.023

MacGregor-Fors, I., and Payton, M. E. (2013). Contrasting diversity values: statistical inferences based on overlapping confidence intervals. PLoS One 8:e56794. doi: 10.1371/journal.pone.0056794

Marlon, J. R., Bartlein, P. J., Gavin, D. G., Long, C. J., Anderson, R. S., Briles, C. E., et al. (2012). Long-term perspective on wildfires in the western USA. PNAS 109 E535-E543 doi: 10.1073/pnas.1112839109

McKendry, I. G., Christen, A., Lee, S.-C., Ferrara, M., Strawbridge, K. B., O’Neill, N., et al. (2019). Impacts of an intense wildfire smoke episode on surface radiation, energy and carbon fluxes in southwestern British Columbia. Can. Atmosp. Chem. Phy. 19, 835-846. doi: 10.5194/acp-19-835-2019

Moore, F. R., Smith, R. J., and Sandberg, R. (2005). "Stopover ecology of intercontinental migrants: En route problems and consequences for reproductive performance," in Birds of Two Worlds: the ecology and evolution of migration, eds R. Greenberg and P. P. Marra (Baltimore, MD: John Hopkins Press), 251-261.

Moran, J. A., Wassenaar, L. I., Finlay, J. C., Hutcheson, C., Isaac, L. A., and Wethington, S. M. (2013). An exploration of migratory connectivity of the Rufous Hummingbird (Selasphorus rufus), using feather deuterium. J. Ornithol. 154:9063. doi: 10.1007/s10336-012-0906-3

Morrison, C. A., Robinson, R. A., Clark, J. A., Risely, K., and Gill, J. A. (2013). Recent population declines in Afro-Palaearctic migratory birds: the influence of breeding and non-breeding seasons. Div. Distrib. 19, 1051-1058. doi: 10.1111/ ddi. 12084

Morrison, M. L., and Meslow, E. C. (1984). Response of avian communities to herbicide-induced vegetation changes. J. Wildl. Manag. 48, 14-22. doi: 10.2307/ 3808449

Mulvihill, R. S., Leberman, R. C., and Wood, D. S. (1992). A possible relationship between reversed sexual size dimorphism and reduced male survivorship in the Ruby-throated hummingbird. Condor 94, 480-489. doi: 10.2307/1369220

NCASI (2009). Forest herbicide effects on Pacific Northwest ecosystems: A literature review. Research Triangle Park, NC: National Council for Air and Stream Improvement, Inc.

NDMC (2020). National Drought Mitigation Center. Boulder: NIDIS

NIDIS (2015). The Great Western Snow Drought of 2015. Boulder: NIDIS.

NIFC (2021). US National Interagency Fire Center: Wildland Fire Open Data. Available online at: https://data-nifc.opendata.arcgis.com/search?tags= HistoricWildfires_OpenData (accessed September 6, 2021)

NOAA (2021). National Weather Service Climate Prediction Centre: (Stand TahitiStand Darwin) Sea Level Pressure Standardized Data. Washington, DC: NOAA.
Nott, M. P., Desante, D. F., Siegel, R. B., and Pyle, P. (2002). Influences of the El Niño/Southern oscillation and the north Atlantic oscillation on avian productivity in forests of the Pacific northwest of North America. Glob. Ecol. Biogeograp. 11, 333-342. doi: 10.1046/j.1466-822X.2002.00296.x

Parker, T. H., Becker, C. D., Sandercock, B. K., and Agreda, A. E. (2006). Apparent survival estimates for five species of tropical birds in an endangered forest habitat in western Ecuador. Biotropica 38, 764-769. doi: 10.1111/j.1744-7429. 2006.00210.x

Partners in Flight (2020). Population Estimates Database, version 3.1. http://pif. birdconservancy.org/PopEstimates

Partners in Flight (2021). Avian Conservation Assessment Database, version 2021.

Paxton, E. H., Durst, S. L., Sogge, M. K., Koronkiewicz, T. J., and Paxton, K. L. (2017). Survivorship across the annual cycle of a migratory passerine, the Willow flycatcher. J. Avian Biol. 48, 1126-1131. doi: 10.1111/jav.01371

Powers, D. R., Brown, A. R., and Van Hook, J. A. (2015). Influence of normal daytime fat deposition on laboratory measurements of torpor use in territorial versus nonterritorial hummingbirds. Physiol. Biochem. Zool. 76, 389-97. doi: $10.1086 / 374286$

Powers, D., Hook, J. V., Sandlin, E., and McWhorter, T. (2010). Arthropod foraging by a southeastern Arizona hummingbird guild. Fac. Publ. Dep. Biol. Mol. Sci. 107. Available online at: https://digitalcommons.georgefox.edu/bio_fac/107 doi: 10.1676/09-179.1

Pyle, P. (1997). Identification Guide to North American Birds: Part 1. Bolinas: Slate Creek Press.

Rockwell, S. M., Wunderle, J. M., Sillett, T. S., Bocetti, C. I., Ewert, D. N., Currie, D., et al. (2017). Seasonal survival estimation for a long-distance migratory bird and the influence of winter precipitation. Oecologia 183, 715-726. doi: 10.1007/s00442-016-3788-x

Rodrigues, L., da, C., Martins, F. I., and Rodrigues, M. (2013). Survival of a mountaintop hummingbird, the Hyacinth Visorbearer Augastes scutatus, in Southeastern Brazil. Acta Ornithol. 48, 211-219. doi: 10.3161/000164513X678801

Rosenberg, K. V., Dokter, A. M., Blancher, P. J., Sauer, J. R., Smith, A. C., Smith, P. A., et al. (2019). Decline of the North American avifauna. Science 366, 120-124. doi: 10.1126/science.aaw1313

Rousseau, J., Alexander, J., and Betts, M. (2020). Using continental-scale bird banding data to estimate demographic migratory patterns for Rufous Hummingbird. Avian Conserv. Ecol. 15:202. doi: 10.5751/ACE-01612-150202

Ruiz-Gutiérrez, V., Doherty, P. F., duardo Santana, C. E., Martínez, S. C., Schondube, J., Munguía, H. V., et al. (2012). Survival of resident neotropical birds: considerations for sampling and analysis based on 20 years of birdbanding efforts in Mexico - supervivencia de aves residentes neotropicales: consideraciones para el muestreo y análisis con base en un esfuerzo de 20 años de anillamiento de aves en México. Auk 129, 500-509. doi: 10.1525/auk.2012. 11171

Rushing, C. S. (2019). Estimability of migration survival rates from integrated breeding and winter capture-recapture data. Ecol. Evol. 9, 849-858. doi: 10. 1002/ece3.4826

Russell, R. W., Carpenter, F. L., Hixon, M. A., and Paton, D. C. (1994). The impact of variation in stopover habitat quality on migrant Rufous hummingbirds. Conserv. Biol. 8, 483-490. doi: 10.1046/j.1523-1739.1994.08020483.x

Russell, S. M., Russell, R. O., Pollock, J., and Hill, A. (2019). The North American banders' manual for banding hummingbirds. California: The North American Banding Council.

Saracco, J. F., Royle, J. A., DeSante, D. F., and Gardner, B. (2010). Modeling spatial variation in avian survival and residency probabilities. Ecology 91, 1885-1891. doi: 10.1890/09-0705.1

Shankar, A., Powers, D. R., Dávalos, L. M., and Graham, C. H. (2020). The allometry of daily energy expenditure in hummingbirds: An energy budget approach. J. Anim. Ecol. 89, 1254-1261. doi: 10.1111/1365-2656.13185

Sillett, T. S., and Holmes, R. T. (2002). Variation in survivorship of a migratory songbird throughout its annual cycle. J. Anim. Ecol. 71, 296-308. doi: 10.1046/ j.1365-2656.2002.00599.x

Slagsvold, T., and Lifjeld, J. T. (1994). Polygyny in birds: the role of competition between females for male parental care. Am. Natural. 143, 59-94. doi: 10.1086/ 285596

State of California (2021). Cal Fire Incident Database: 2013-2021. California: California Department of Forestry and Fire Protection 
Stiles, F. G. (1992). Effects of a severe drought on the population biology of a tropical hummingbird. Ecology 73, 1375-1390. doi: 10.2307/1940683

Suarez, R. K. (1992). Hummingbird flight: Sustaining the highest mass-specific metabolic rates among vertebrates. Experientia 48, 565-570. doi: 10.1007/ BF01920240

Supp, S. R., Sorte, F. A. L., Cormier, T. A., Lim, M. C. W., Powers, D. R., Wethington, S. M., et al. (2015). Citizen-science data provides new insight into annual and seasonal variation in migration patterns. Ecosphere 6, 1-19. doi: 10.1890/ES14-00290.1

Taylor, C. M., and Stutchbury, B. J. M. (2016). Effects of breeding versus winter habitat loss and fragmentation on the population dynamics of a migratory songbird. Ecol. Appl. 26, 424-437. doi: 10.1890/14-1410

USDA (2021). United States Department of Agriculture: Natural Resources Conservation Service Colorado. Washington, DC: USDA.

Wade, M. J. (1979). Sexual selection and variance in reproductive success. Am. Natural. 114, 742-747. doi: 10.1086/283520

Waser, N. M., and Price, M. V. (2016). Drought, pollen and nectar availability, and pollination success. Ecology 97, 1400-1409. doi: 10.1890/151423.1

Weidensaul, S., Sargent, R. R., Sargent, M. B., and Zenzal, T. J. (2020). "Rubythroated Hummingbird (Archilochus colubris), version 1.0," in Birds of the World, ed. P. G. Rodewald (Ithaca, NY: Cornell Lab of Ornithology). doi: 10.2173/bow.rthhum.01

Williamson, J. L., and Witt, C. C. (2021). A lightweight backpack harness for tracking hummingbirds. J. Avian Biol. 52:2802. doi: 10.1111/jav.02802

Wilson, S., Collister, D., and Wilson, A. (2011). Community composition and annual survival of lowland tropical forest birds on the Osa Peninsula, Costa Rica. Ornitol. Neotrop. 22:421.

Wilson, S., Saracco, J. F., Krikun, R., Flockhart, D. T. T., Godwin, C. M., and Foster, K. R. (2018). Drivers of demographic decline across the annual cycle of a threatened migratory bird. Sci. Rep. 8, 1-11. doi: 10.1038/s41598-018-256 33-z

Wilson, S., Schuster, R., Rodewald, A. D., Bennett, J. R., Smith, A. C., La Sorte, F. A., et al. (2019). Prioritize diversity or declining species? Trade-offs and synergies in spatial planning for the conservation of migratory birds in the face of land cover change. Biol. Conserv. 239:108285. doi: 10.1016/j.biocon.2019.10 8285

Winkler, D. E., Butz, R. J., Germino, M. J., Reinhardt, K., and Kueppers, L. M. (2018). Snowmelt timing regulates community composition, phenology, and physiological performance of alpine plants. Front. Plant Sci. 9:1140. doi: 10. 3389/fpls.2018.01140

Winnick, B., and Dzialowski, E. M. (2013). The effects of glyphosate based herbicides on chick embryo morphology during development. FASEB J. 27:874. doi: 10.1096/fasebj.27.1_supplement.874.12

Wipf, S., Stoeckli, V., and Bebi, P. (2009). Winter climate change in alpine tundra: plant responses to changes in snow depth and snowmelt timing. Clim. Chan. 94, 105-121. doi: 10.1007/s10584-009-9546-x

Woodrey, M. S., and Chandler, C. R. (1997). Age-related timing of migration: geographic and interspecific patterns. Wilson Bull. 109, 52-67.

Zhao, Q., Mitchell, G. W., Cadman, M., Kusack, J., Evans, D., Bumelis, K., et al. (2022). Integrating regional and site-level data to assess drivers of population decline in a threatened aerial insectivorous bird. Biol. Conserv. 265:109424. doi: 10.1016/j.biocon.2021.109424

Conflict of Interest: The authors declare that the research was conducted in the absence of any commercial or financial relationships that could be construed as a potential conflict of interest.

Publisher's Note: All claims expressed in this article are solely those of the authors and do not necessarily represent those of their affiliated organizations, or those of the publisher, the editors and the reviewers. Any product that may be evaluated in this article, or claim that may be made by its manufacturer, is not guaranteed or endorsed by the publisher.

Copyright $\odot 2022$ Drake, Bishop, Moran and Wilson. This is an open-access article distributed under the terms of the Creative Commons Attribution License (CC BY). The use, distribution or reproduction in other forums is permitted, provided the original author(s) and the copyright owner(s) are credited and that the original publication in this journal is cited, in accordance with accepted academic practice. No use, distribution or reproduction is permitted which does not comply with these terms. 